\title{
Correction to: Impact of Body Mass Index (BMI) on perioperative outcomes following minimally invasive retromuscular abdominal wall reconstruction: a comparative analysis
} Alex Addo ${ }^{1} \cdot$ Richard Lu$^{1} \cdot$ Andrew Broda $^{1} \cdot$ Philip George $^{1} \cdot$ Nick Huerta $^{1} \cdot$ Adrian Park $^{1} \cdot$ H. Reza Zahiri
Igor Belyansky

Published online: 2 November 2020

(c) Springer Science+Business Media, LLC, part of Springer Nature 2020

Correction to: Surgical Endoscopy

https://doi.org/10.1007/s00464-020-08069-3

This article was updated to correct the labeling of major column 3 in Table 2 to read "BMI $>35$," not "BMI $\leq 35$."

Publisher's Note Springer Nature remains neutral with regard to jurisdictional claims in published maps and institutional affiliations.

The original article can be found online at https://doi.org/10.1007/ s00464-020-08069-3.

Igor Belyansky

ibelyansky@aahs.org

1 Department of Surgery, Anne Arundel Medical Center, 2000

Medical Parkway, Suite 100, Annapolis, MD 21401, USA 